\title{
The role of dietary supplements in cosmetology therapy based on deep chemical peels
}

\author{
Rola suplementów diety u terapii kosmetologicznej \\ opartej o glęboko dzialajace peelingi chemiczne
}

\section{SUMMARY}

Treatments based on deep chemical peels are aimed at cell renewal, accelerating the synthesis of collagen, elastin and glycosaminoglycans, and consequently improving skin firmness, reducing wrinkles and scars. Due to the small molecule and low $\mathrm{pH}$, chemical peels interact at the level of the living layers of the epidermis and dermis. They lead to controlled skin damage and initiate regeneration and remodeling processes. The consequence of using peels at the level of the dermis is the formation of new cells capable of synthesizing more collagen, elastin and hyaluronic acid. During treatments aimed at cell exchange and stimulation of fibroblasts, the demand for amino acids, microelements and vitamins increases. Their supply is complemented by dietary supplements.

The aim of the study was to show the role of dietary supplements in cosmetology treatments based on chemical peels acting at the level of the dermis. The synergy of simultaneous use of dietary supplements and chemical peels as well as the positive effect of supplementation on the effects visible on the skin was indicated.

Keywords: cosmetology treatments, chemical peels, dietary supplements, fibroblast metabolism, collagen synthesis

\section{STRESZCZENIE}

Zabiegi oparte na głębokich peelingach chemicznych mają na celu odnowę komórkową, przyspieszenie syntezy kolagenu, elastyny i glikozaminoglikanów, a w konsekwencji poprawę jędrności skóry, spłycenie zmarszczek i blizn. Mała cząsteczka i niskie pH sprawiają, że peelingi chemiczne oddziałują na poziomie żywych warstw naskórka i skóry właściwej. Prowadzą do kontrolowanego uszkodzenia skóry i inicjują procesy regeneracji i przebudowy. Konsekwencją stosowania peelingów na poziomie skóry właściwej jest powstanie nowych komórek zdolnych do syntezy większej ilości kolagenu, elastyny i kwasu hialuronowego. Podczas zabiegów mających na celu wymianę komórkową oraz stymulację fibroblastów, rośnie zapotrzebowanie na aminokwasy, mikroelementy, witaminy. Ich podaż uzupełniają suplementy diety.

Celem pracy było wskazanie roli suplementów diety w zabiegach kosmetologicznych opartych na peelingach chemicznych działających na poziomie skóry właściwej. Wskazano na synergię równoczesnego stosowania suplementów diety oraz peelingów chemicznych oraz pozytywny wpływ wprowadzenia suplementacji na efekty widoczne na skórze.

Słowa kluczowe: zabiegi kosmetologiczne, peelingi chemiczne, suplementy diety, metabolizm fibroblastów, synteza kolagenu 


\section{INTRODUCTION}

The skin is the largest human organ, accounting for 12 to $15 \%$ of the total body weight. Its surface varies between 1.5$2 \mathrm{~m}^{2}$ and is the second largest organ in contact with the external environment, after the mucous membranes. UV radiation, free radicals, inadequate care, and chronic stress, diseases and deficiencies cause the skin to change appearance and age. Wrinkles, discoloration appear, tension drops.

Cosmetic treatments are designed to restore the healthy appearance of the skin and reduce the symptoms of aging. The most frequently chosen ones are deep-acting chemical peels. According to the American Society of Plastic Surgeons ASPS, it is the third most popular group of procedures performed in the US in 2016. Botulinum toxin and fillers were ranked first and second, respectively.

\section{CHEMICAL PEELS. TYPES AND MECHANISM OF ACTION}

Chemical structure - the location of the carboxyl (-COOH) and hydroxyl (-OH) groups determines the type of chemical acid. There are AHA (alpha-hydroxy acids), BHA (beta-hydroxy acids) and PHA (polyhydroxy acids) [1]. The depth of the peeling action depends on the particle size, $\mathrm{pH}$ and $\mathrm{pKa}$ of the acid, the carrier of the substance used, the procedure of the treatment and the condition of the skin. The higher the concentration and the lower the $\mathrm{pH}$, the more intense the peeling effect. Preceding the peeling application with microdermabrasion, cavitation peeling and disturbance of the hydro-lipid barrier increase the penetration of the peeling. The most powerful acids used in cosmetology include:

- glycol peeling. Glycolic acid has a small molecule and belongs to the alpha-hydroxy acid group. It is the most commonly used acid in chemical peels. It occurs naturally in sugarcane;

- pyruvic peeling. Pyruvic acid is one of the $\alpha$-keto acids. Pyruvic acid in the water environment turns into mildly acting lactic acid. It is present in fermented fruit, vinegar;

- salicylic peeling. Salicylic acid belongs to BHA acids. It is lipophilic and easily penetrates the epidermal barrier. Salicylic acid is extracted from willow bark;

- trichloroacetic peeling (TCA). Trichloroacetic acid is cytotoxic, its use leads to protein coagulation. TCA is formed by the oxidation of chloral [2, 3].

Deep chemical peels penetrate the subsequent layers of the epidermis and reach the dermis. There, they damage individual cell structures or initiate cell death processes apoptosis. As a result, cell renewal takes place [4]. The resulting cells are able to produce more collagen, elastin and glycosaminoglycans (GAG). The mechanism of peeling action can be divided into two phases:

- catabolic phase - reactions of decomposition of complex compounds into simpler compounds, leading to the for- mation of adenosine triphosphate (ATP). The proton released by the acid breaks the peptide bonds. The catabolic phase leads to the breakdown of intercellular bonds and proteins;

- anabolic phase - synthesis of compounds composed of simpler ones, requiring the supply of ATP energy. The products of synthesis are support proteins, glycosaminoglycans and keratin that forms the epidermis. The anabolic phase is opposite to the catabolic phase.

\section{PROTEIN SYNTHESIS AND GAG IN THE DERMIS}

The cells of the dermis - fibroblasts - are responsible for the production of collagen, elastin and glycosaminoglycans. Collagen and elastin build the extracellular space of connective tissue, and are responsible for skin tightness and hardness. In turn, the role of hyaluronic acid is to bind water and maintain hydration.

Collagen synthesis takes place in two stages.

- Stage 1. Collagen synthesis in fibroblasts. This process can be divided into 3 parts: gene transcription, translation and post-translational modification. In the latter, lysine and proline residues receive additional hydroxyl groups. This happens with the participation of hydroxylase enzymes, which require vitamin $\mathrm{C}$ as a cofactor. The first stage ends with the formation of procollagen.

- Stage 2. Collagen maturation takes place outside the fibroblast, in the intercellular space. Subsequently, procollagen is split and tropocollagen is formed. Finally, tropocollagen molecules combine with each other with the help of lysyl oxidase - an enzyme dependent on copper, forming collagen fibers [5].

Elastin synthesis is similar. Two amino acids are necessary for the production of elastin: proline and glycine. Elastin (tropoelastin) formed inside fibroblasts is secreted into the extracellular matrix. Elastin fibers are formed by the binding of polypeptide chains between lysine residues.

Hyaluronic acid (HA) is, chemically, sugar. Its production is different to that of proteins. Hyaluronic acid biosynthesis takes place on the inner surface of the fibroblast cell membrane. Hyaluronine synthases participate in the process. The HA chain grows on the inside of the cell membrane and the end of the chain moves out of the cell membrane. This mechanism enables the formation of long hyaluronan polymers. HA chains create an environment with the desired degree of hydration and physical protection for fibroblasts [6]. The latter means that HA is also attributed an antioxidant effect, limiting the reaching of free radicals inside the fibroblasts.

\section{ESSENTIAL SUBSTRATES IN THE SYNTHESIS OF COLLAGEN, ELASTIN AND GAG}

The following amino acids take part in the collagen and elastin synthesis: lysine, proline, glycine, vitamin C, copper 
and iron. In turn, the synthesis of hyaluronic acid requires a glucose derivative - glucosamine [7].

At the same time, it should be remembered that the production of proteins and hyaluronic acid takes place with the participation of ATP cellular energy. ATP synthesis takes place in the mitochondria and is produced with the participation of, among others, oxygen, glucose and coenzyme Q10.

Cosmetic treatments with the use of chemical peels initiate the synthesis processes. Their implementation, however, is not synonymous with reducing wrinkles and improving skin tension and hydration. In order to achieve the desired effect of the treatment, the above-mentioned substrates involved in the production of proteins and GAGs must be present at the skin level.

Deficiencies of amino acids, vitamins and microelements limit the effectiveness of chemical peels. In extreme cases, such as anemia, they can cause chronic inflammation and accelerate skin aging.

Cosmetic therapy aimed at smoothing scars, wrinkles and improving tension in addition to treatments should take into account the increased supply of the above-mentioned ingredients in the diet and / or in dietary supplements.

\section{SUPPLEMENTATION IN PRACTICE}

Deep chemical peels and the related skin reconstruction and protein synthesis require a higher than physiological demand for micronutrients. The supply of amino acids and vitamins in the diet may be insufficient. Dietary supplements are the solution.

According to the definition proposed in the Food and Nutrition Safety Act, a dietary supplement is understood as a substance composed of nutrients and is treated as a supplement to normal food [8]. It is a concentrated source of vitamins, minerals and other substances, e.g. amino acids, fatty acids, fiber and plant extracts; and its form must be dosable. Hence, products in the form of capsules, tablets, sachets with powder, ampoules with liquid are distinguished. Food supplements are not products having the properties of a medicinal product within the meaning of the pharmaceutical law. They were included in the group of food products [8].

The purpose of dietary supplements is to maintain and / or improve the body's homeostasis. Unlike a drug that is needed in an illness, a dietary supplement is designed for a healthy person and is designed to help him maintain metabolic and physiological functions at the highest level. Dietary supplements play an important role in cosmetology therapy. Along with cosmetology treatments and home care, they are part of a comprehensive skin therapy plan.

An interview and laboratory tests help determine any deficiencies. Their supplementation is the first and most im- portant criterion for choosing a product. Another is the needs of the skin and goals in cosmetology therapy. The demand for micro- and macroelements increases in inflammatory procedures leading to cell renewal, and the set goals in cosmetology therapy help in choosing the right preparation. Moisturizing treatments can be combined with supplements that increase the level of hyaluronic acid, while in anti-inflammatory therapy - acne vulgaris, acne mature, acne erythematosus, preparations influencing the immune system can be used. The combination of cosmetology treatments and supplementation makes the skin reach the ingredients that complement each other action, making the therapy more effective, and the effects - long-term.

Supplements that are used in treatments with chemical peels are preparations based on the substances listed below.

- Amino acids. The essential amino acids for the synthesis of collagen and elastin are: lysine, proline, and glycine. When choosing a ready-made preparation, pay attention to the content / concentration of the ingredients. The daily dose of each of the mentioned amino acids should be at least $500 \mathrm{mg}[9,10]$.

- Coenzyme Q10. The process of collagen and elastin synthesis requires the input of ATP cellular energy. The presence of coenzyme Q10 increases the efficiency of the mitochondria, energy synthesis is faster. The best form of coenzyme Q10 is ubiquinone [11].

- Micronutrients. The most important micronutrients involved in the synthesis of supporting proteins are iron and copper. In the intestinal cells - enterocytes - copper is a cofactor for iron absorption. Copper deficiencies, or imbalances between iron and copper in favor of iron, result in the accumulation of iron in the gut. It is not used by the body. Copper and iron supplementation should take place at the same time [12].

- Vitamin C. Bioavailability, ie the effective concentration of vitamin $\mathrm{C}$, depends on its effective absorption from the intestine and excretion through the kidneys. The latter the excretion of vitamin $\mathrm{C}$ by the kidneys is a determinant of the daily dose of vitamin $\mathrm{C}$, which for an adult has been set at $1000 \mathrm{mg}$ [13].

When using dietary supplements, remember that the body first transports ingredients to the most important organs (heart, liver, brain) and replenishes deficiencies inside the body. Only later do they find their way to the skin. For this reason, supplementation cannot last less than 3-6 months. It is worth starting supplementation at least a month before a series of planned cosmetology treatments.

\section{SUMMARY}

Conditioning the skin with chemical peels and home care cosmetics is only part of the therapy, the second equally important is the lifestyle (diet, physical activity, circadian 
rhythm) and dietary supplements. The latter supplement the deficiencies and, with the increased demand for microelements in peeling therapies, provide ready-made substrates. Cosmetic therapy that combines all the above-mentioned tools leads to clear and long-term effects on the skin. This translates into the satisfaction of both the client and the specialist conducting the therapy.

\section{REFERENCES / LITERATURA}

1. Berson DS, Cohen JL, Rendon MI, et al. Clinical role and application of superficial chemical peels in today's practice. J Drugs Dermatol. 2009;(9):803-811.

2. Fischer TC, Perosino E, Poli F, et al. Cosmetic Dermatology European Expert Group. Chemical peels in aesthetic dermatology: an update 2009. J Eur Acad Dermatol Venereol. 2010;24(3):281-292.

3. Tse Y, Ostad A, Lee HS, et al. A clinical and histologic evaluation of two medium-depth peels glycolic acid versus Jessner's trichloroacetic acid. Dermatol Surg. 1996;22(9):781-786.

4. Nelson BR, Fader DJ, Gillard M, et al. Pilot histologic and ultrastructural study of the effects of medium-depth chemical facial peels on dermal collagen in patients with actinically damaged skin. J Am Acad Dermatol. 1995;32(3):472-478.
5. The National Center for Biotechnology Information https://www.ncbi. nlm.nih.gov/books/NBK507709/. Accessed 11.08.2020.

6. Nagaoka I, Tsuruta A, Yoshimura M. Chondroprotective action of glucosamine, a chitosan monomer, on the joint health of athletes. Int J Biol Macromol. 2019;132:795-800.

7. Yeung BKS, Chong PYC, Petillo PA. In: Wang PG, Bertozzi CR, ed. Glycochemistry. Principles, Synthesis and Applications. New York City: Marcel Dekker, Inc; 2001: 425-492.

8. Ustawa o bezpieczeństwie żywności i żywienia z dnia 25 sierpnia 2006 r., Dz. U. 2006 r. Nr 171, poz. 1225 z późn. zm.

9. Peacock Jr EE. Effect of dietary proline and hydroxyproline on tensile strength of healing wounds. Proc Soc Exp Biol Med. 1960;105:380-383.

10. Murakami H, Shimbo K, Inoue Y, et al. Importance of amino acid composition to improve skin collagen protein synthesis rates in UV-irradiated mice. Amino Acids. 2012;42:2481-2489.

11. Suksomboon N, Poolsup N, Juanak N. Effects of coenzyme Q10 supplementation on metabolic profile in diabetes: a systematic review and meta-analysis. J Clin Pharm Ther. 2015;40:413-418.

12. Gulec S, Collins JF. Investigation of iron metabolism in mice expressing a mutant Menke's copper transporting ATPase (Atp7a) protein with diminished activity (brindled; Mo (Br) (/y)). PLoS One. 2013;8:e66010.

13. Henmi H, Endo T, Kitaiima Y, et al. Effects of ascorbic acid supplementation on serum progesterone levels in patients with a luteal phase defect. Fertil Steril. 2002;80:459-461. 